\title{
Potential for opportunity recognition along the stages of entrepreneurship
}

Kishinchand Poornima Wasdani ${ }^{1^{*}}$ and Mary Mathew ${ }^{2,3,4,5}$

\author{
* Correspondence: \\ kishinchandpoornima@gmail.com \\ ${ }^{1}$ Department of Management \\ Studies, Indian Institute of Science, \\ Bangalore 560012, India \\ Full list of author information is \\ available at the end of the article
}

\begin{abstract}
The study primarily verifies whether ORP differs in stages of entrepreneurship and aims at identifying factors that influence ORP in different stages of entrepreneurship. The stages of entrepreneurship include pre-stage (individuals planning to start ventures), early-stage (entrepreneurs with ventures less than 3 years old) and late-stage (entrepreneurs with ventures more than 3 years in existence). The factors that were studied include personal factors (cognitive style, self-efficacy and motivation) and interpersonal factors (bridging social capital and bonding social capital). The results indicate the influence of different factors in different stages of entrepreneurship.
\end{abstract}

Keywords: Entrepreneurship; Social capital; Self-efficacy; Cognitive style and Motivation

\section{Background}

Entrepreneurial individuals are success driven, and hence are more likely to engage in the right kind of opportunity recognition to ensure that they are successful. Entrepreneurial opportunities are believed to exist when individuals have a special understanding of the value of uncommon opportunities and act upon this understanding, which results in entrepreneurial income or "rent". If the individual does not act on this perception it results in an entrepreneurial loss (Alvarez and Barney 2000). One of the various definitions of opportunity recognition given by Lumpkin and Lichtenstein (2005:457) is "the ability to identify a good idea and transform it into business concepts that add value and generate revenue". This definition makes an emphasis that opportunity recognition is an inseparable part of entrepreneurship.

According to several researchers like Shane and Venkataraman (2000), Krueger (2003), Sarason et al. (2006) and Mitchell et al. (2004), opportunity recognition is an integral part of the entrepreneurship process. Individuals possessing this skill have probably a higher inclination to entrepreneurship than the ones who do not posses them (Shane et al. 2003). There are a number of factors that influence opportunity recognition of entrepreneurs including individual traits and networking capabilities (Nicolaou et al. 2009). Without an opportunity, whether created or discovered, entrepreneurial activities cannot exist even though the individual has all the characteristics that influence the success of the venture creation process (Short et al. 2010). In other words it is a fundamental unit of entrepreneurship. Opportunity need not always be a break-through; it can sometimes be a traditional idea with a new approach or a mix of existing ideas. However the resources available to convert these ideas to opportunities, 
decides the ways of its pursuit (Stevenson 1983). The situations identified by Stevenson (1983) that give rise to opportunities, are: changes in technology, changes in the purchasing power and the spending behavior of customers, changes in the living standards of consumers and changes in the regulation of products and services. Further there are two ways in which an opportunity is identified: either by "motivated search" or "serendipitous discovery" (Dimov 2007, p 717).

Gartner (1990, p.27) emphasized, "Entrepreneurs are distinguished by their propensity to recognize opportunities". Opportunity recognition according to Dyer et al. (2008) will not only differentiate an entrepreneur from a non-entrepreneur but will also support the fact that entrepreneurs are different from employee-managers. The differences in the personality traits, social networks and cognitive styles largely influence the opportunity recognition of entrepreneurs (Dyer et al. 2008). Studying opportunity recognition retrospectively suffers from recollection bias, glorification of success and suppression of failures (Dimov 2007). Thus it is better to study opportunity recognition in relation to the factors that influence them, which is the basis of this study. In this paper we attempt to distinguish entrepreneurs with high potential for opportunity recognition and entrepreneurs with low potential for opportunity recognition on personal factors (self-efficacy, cognitive styles and motivation), and interpersonal factor (social networks).

\section{Review of literature}

\section{Potential for opportunity recognition of entrepreneurs}

It is interesting to note that a body of literature has emerged over the last 21 years on this topic. Authors looked at opportunity recognition from different perspectives of entrepreneurship. They have either described the term opportunity recognition (De Koning 1999; Ardichvili et al. 2003; De Carolis and Saparito 2006 and Sambasivan et al. 2009) or provided information on individuals who have and do not have opportunity recognition skills (Shane and Venkataraman 2000 and Singh et al. 1999).

The opportunity recognition framework has been challenged by a number of authors, coming from a variety of theoretical perspectives. There is the ontological critique, given by Alvarez and Barney (2007), who argued that opportunities are endogenously created, rather than being "discovered". Literature on effectuation (Sarasvathy and Dew 2005) and bricolage (Garud and Karnøe, 2003) argues that entrepreneurship is not about the recognition of exogenously given opportunities, but about experimentation and incremental learning by taking advantage of resources at hand. Writers such as Klein (2008) and Davidson (2001) call for abandoning the construct of opportunity altogether, arguing that it takes our focus away from actions such as making an investment, starting a firm etc. that are aimed towards making a profit, and not at hypothetically exploiting an "opportunity".

Whether opportunities are discovered or created has been a subject of continuous debate. An opportunity is said to have been "discovered", when it is exogenously recognized, i.e. individuals seize opportunities when they are alert to them (Kirzner, 1997). On the other hand an opportunity is said to have been "created", when it is recognized endogenously through imagination and effectuation (Sarasvathy, 2001). These arguments have been continued with words such as "found" and "made" used in place of "discovery" and "creation" of opportunities respectively (Venkataraman, 2003). It has also been further argued whether opportunities are either objective or subjective or 
both (Alvarez and Barney, 2007) and if business ideas are different from opportunities Shane 2012). Several scholars (Sarasvathy and Dew 2005; Guard \& Giuliani 2013; Davidson 2001) and in particular Alvarez and Barney (2013), who gave the "relational and temporal approach" have shown that the process of opportunity recognition involves both creation and discovery of opportunities and that they indeed occur simultaneously. Drawing from the narrative proposition of Bruner (1990), we understand that the process of opportunity recognition is both objective (i.e., it occurs due to changes such as scientific advances, political and regulatory, demographic and social shifts) and subjective (i.e., it occurs due to an individual's characteristics). Shane (2012) explained the difference between business ideas and opportunities by stating that ideas are the carriers of opportunities.

Our research attempts to explore the subjective influence, and in particular the influence of both personal and interpersonal factors on the process of opportunity recognition among entrepreneurs.

The various definition of opportunity recognitions are as follows: deBono (1978) definition is "course of action that is possible and worth pursuing"; Long and McMullan (1984) "An elaborated vision of a new venture which involves a searching preview of the mechanism of translating the concept into reality with an industrial setting"; Hulbert et al., (1997) defines it as "the chance to meet an unsatisfied need that is potentially profitable"; Santos and Eisenhardt (2005) "entrepreneurs perceive new opportunities for the creation of value and construct a market around those opportunities" reported by Hills et al. (2004) p.2.

Shane and Venkataraman differentiate individuals who can recognize the potential of an opportunity from the ones cannot. They do this differentiation based on two dimensions, one possession of prior information, and second the cognitive skills to evaluate them. The essential characteristics of opportunities that make them vulnerable for exploitation are that demand is large, profit margins are high, cost of capital is low, moderate density of competition, opportunity cost is low and technology life cycle is small (Shane and Venkataraman 2000). The essential characteristics of individuals who exploit opportunities are possession of greater financial capital, social ties with resource providers, greater self-efficacy and motivation to achieve (Shane and Venkataraman, 2000). Similarly Singh et al. (1999) studied opportunity recognition as an individual's alertness in identifying opportunities. Drawing from the works of several researches (for example Bhave 1994; Timmons 1994 and Shane and Venkataraman 2000) it can be inferred that the core activity of an entrepreneur is venture formation and the essential part of this activity is opportunity recognition.

Timmons and Spinelli (2007) emphasize the importance of opportunity recognition for entrepreneurs, by providing evidence that shows entrepreneurship gets continuously renewed through the process of opportunity identification. The framework proposed by them about entrepreneurial process constitutes three important elements namely, opportunity evaluation, resource marshalling and team formation.

Thus opportunity recognition skill is inevitable for an entrepreneur who wishes to create ventures that outlive the entrepreneur.

The decision to choose between the two types of opportunities namely optimization of existing resources by creating new means of utilizing the resources and finding of new resources depends upon four factors namely access to capital, scale economies, complementary assets and learning curve of the entrepreneur (Shane and Venkataraman, 2000). 
Singh et al. (1999, p.1) borrows from Christensen et al. (1989) the definition of opportunity recognition as "perceiving the possibility for new profit potential through founding and forming of new venture and significant improvement of an existing venture". This definition emphasizes that the act of opportunity recognition is not a one-time activity of an entrepreneur instead is a perpetual one that encompasses perception, discovery and creation (Singh et al. 1999). De Koning (1999, p.3) defines opportunity recognition as an "evolution of initial idea into full blown business concepts". The difference between Singh and De Koning's definitions is that the former emphasize on opportunity recognition as ongoing activity of the entrepreneur whereas the latter, limits its role to the originating phase of the venture creation.

Singh et al. (1999) emphasize that opportunity recognition is not before or after the business formation; instead it is continuous with the life cycle of the venture. The strategies the entrepreneur applies when identifying opportunities are by adapting products and services to the customer preferences, adopting proactive approach to investigate the ideas, interacting with the people in the market, getting an experience of the market and by personalizing the idea (Hills et al. 2004).

\section{Stages of entrepreneurship}

DeTienne (2010, p.206) reported the stages of entrepreneurship identified by Reynolds and White (1997) as "conception (adult population), gestation (nascent entrepreneurs), infancy (new firms) and adolescence (established firms)". This research refers to the nascent entrepreneurs as pre-stage-entrepreneur, defined as "Persons who are in the start up process of their planned ventures, beginning with initial startup activities such as contact with a startup advising centre, development of business plan and ends before market entry" (Korunka et al. 2003, p.26). In the infancy stage individuals do not have a psychological contract with the firm and the probability of exit is higher. In the adolescence the entrepreneurs have developed the psychological contract with the firm and are keenly interested its everyday activities (DeTienne 2010).

Early-stage-entrepreneurs (new business owner) are defined as "owners of small businesses that have already started business activities and have not been in the business for more than three years" (Korunka et al. 2003, p.26). Baron (2002) denotes these stages as prelaunch, launch and post launch phases of entrepreneurship cycle.

\section{Factors influencing opportunity recognition in entrepreneurs}

Entrepreneurs' possess characteristics that are commonly found among them, which influence their ability to recognize novel opportunities and assist them in moblising the resources required for venture creation (Alvarez and Busenitz 2001). Also variability among the entrepreneurs on these factors will decide their performance in terms of recognizing profitable opportunities (Alvarez and Busenitz 2001). De Carolis and Saparito (2006) find that combined presence of cognition and social capital results in successful opportunity recognition than the absence of them. Research has also noticed that individuals with similar skills, levels of knowledge, and abilities may not be able to realize opportunities, hence the study has moved beyond these factors and looks into individual's variability in terms of self-efficacy, cognition, social skills, perseverance, human capital (experience and education) and motivation (Alvarez and Busenitz, 2001). 
While there are a number of factors this study restricts itself to factors that were found to have strong research support which include the self-efficacy, cognition and social capital.

\section{Social capital of entrepreneurs}

Entrepreneurs are very good networkers since they understand that they need people who can help in their venture launching and growth activities (Craig and Lindsay 2001).

Burt (1997) defines entrepreneurs as "individuals who are skilled at building interpersonal bridges and spanning structural holes". Social network provide entrepreneurs with opportunities, converting them into rewarding ventures, depends on the entrepreneur's skill that include cognitive skills and socializing skills (Burt 1997). In other words, it is an art of making others believe in your creation (Gartner et al. 1992). Social networks benefit entrepreneurs by providing resources that they do not own (Singh et al. 1999). The network is found to be a critical success factor of entrepreneurship. The more the entrepreneur spends time with his team and stakeholders (customers, suppliers, competitors and employees) the more he or she is successful in their ventures than the ones who do not create and communicate with such networks (Lee and Tsang 2001). The network is made of three important elements namely the content, the governance and pattern of the exchanges between the members. The content can be of two types reputational or signaling, governance depends on the trust that the members' share among themselves and patterns can be direct or indirect connections (Hoang and Antoncic 2003). The three components will have to be synchronized in such a way that the probability of getting resources from the networks is enhanced (Hoang and Antoncic 2003). Social networks are present around the entrepreneur by virtue of religion, education, family, community, ethnicity, social class, economic class, age, neighborhood and so forth (Egbert 2009). The ability to derive social capital from these networks will define the value of the social networks. Social capital is "the sum of the actual and potential resources individuals obtain from their relationships with others" (Nahapiet and Ghoshal 1998, p.243). The size of the network, the centrality of the member and the diversity of the network control the amount of social capital that can be derived from the networks (Hoang and Antoncic 2003). The more the use of social networks the higher is the growth of the venture (Hoang and Antoncic 2003).

Baron (2004) elaborated on the benefits of social capital for an entrepreneur as access to investors, suppliers, customers and employees, trust building and cooperation among business partners (teams), expansion of personal networks, which eventually contribute to the venture success and battling the information asymmetries. Johannisson (2000) emphasized on the role of social capital as sensitizer, motivator and developer of alertness to identify an opportunity and ways to exploit it. According to him, entrepreneurs create ties either deliberately or serendipitously with other individuals. In either of the cases, these ties are the reflection of the entrepreneur's personality, provides a direction to their decision-making, supports them with resources and helps in maintaining their emotional and cultural capital.

Putnam (1995) points out that there are two types of social capital namely bridging and bonding depending upon the strength of the ties in the network. Weak ties give rise to bridging social capital and strong ties form bonding social capital. The two types of social capital can influence the formation of the other depending upon the 
socializing skills of the individual. Bridging social capital in the words of Putnam (1995) is a benefit derived from large number of short terms relationships with individuals of diverse interest. On the other hand bonding social capital is an effect of long terms relationships with few intimate connections that may not have diverse backgrounds. The advantages of bridging social capital are different from the bonding social capital. The former gives access to wider and current information thus combating the bounded rationality of the individuals and latter provides an emotional and social support (Putnam 1995; Singh et al. 1999). The benefits of bonding ties include important advantages such as reduced turnaround time for information, high levels of trust, predictability and ease of communication of problems and seeking of solution to them from the group and provide highly reliable information (Bhagavatula et al. 2010). Networks also help in asset parsimony (acquiring resources at a price that is lower than the market price), which creates a competitive advantage for the firm (Bhagavatula et al. 2010). Singh et al. (1999) makes compelling emphasis about the role of networks on opportunity recognition. They find that networked entrepreneurs recognize more opportunities than the solo entrepreneurs, with the help of their social networks, whereas the solo entrepreneur relies more on their experience in and knowledge of the market.

This brings us to the research question:

Does bridging and bonding social capital differ in their influence on potential for opportunity recognition along the stages of entrepreneurship?

\section{Self-efficacy of entrepreneurs}

The literature does enumerate the behaviors that are associated or unique to entrepreneurial activities (domain) for example risk-taking, innovation, achievement orientation etc. The underlying cause of all these behaviors is the self-efficacy of the individual (Chen et al. 1998). According to Bandura (1986, p.231), "self-efficacy is concerned not with the skills one has but with a judgment of what one can do with the skills one possess". Self-doubt of an individual about his/her abilities can abstain the individual from indulging into entrepreneurial expedition more than lack of abilities. In other words the belief in abilities is more important than even the possession of them and any past experience of the task (Chen et al. 1998). The reason behind this is that self-efficacy creates an intrinsic motivation in the individual, which develops a resilience to face any loss or failure during the execution of the toughest task (Bandura 1986).

Again Bandura (1993) emphasizes the role of self-efficacy in human behaviors that distinguishes entrepreneurs from the non-entrepreneurs. The rationale that self-efficacy improves the performance of an individual is that it develops a persistent behavior in times of uncertainty, motivates the individual to aim for higher standards of achievement and above all decreases the fear of threat (Bandura, 1986). Self-efficacy also determines the kind of task in terms of its challenges an individual will undertake and the amount of persistence he/she will engage with in completing the undertaken task. This can be easily associated with the entrepreneurial activities, which are by nature challenging and imbibe attainable outcomes (Alvarez and Busenitz, 2001). In addition, self-efficacy can predict the kind and number of opportunities recognized by the entrepreneur (Krueger et al. 1994).

Chen et al. (2001, p.63) in their work quotes Eden's definition of general self-efficacy as "one's belief in one's overall competence to effect requisite performance across a wide 
variety of achievement situations" or "individuals' perception of their ability to perform across a variety of different situations".

Entrepreneur's self-efficacy is defined as "a person's belief in their ability to successfully launch an entrepreneurial venture" (McGee et al. 2009, p. 965). It can be enhanced by training and education to improve the decision-making processes of the entrepreneurs (McGee et al. 2009) and is the best variable to predict entrepreneur's performance (Shane et al. 2003). The entrepreneurial self-efficacy varies with the task of the entrepreneur. Even in the presence of a clear indication of existence of promising opportunity, an individual who has low self-efficacy will not be able to perceive nor be able to maximize the utilization of the opportunity (Bandura 1986). This brings us to the research question:

Does self-efficacy differ in its influence on potential for opportunity recognition along the stages of entrepreneurship?

\section{Cognitive styles of entrepreneurs}

According to Alvarez and Busenitz (2001, p.759) cognitive skills of entrepreneurs are abilities "to frame situations in an opportunistic manner" and is a basis of how entrepreneurs methodize the resources required for evaluating and exploiting opportunities. Cognitive skills are the strongest discriminating factor between opportunity 'recognizers' and 'non-recognizers' since cognition impacts the ways in which entrepreneurs evaluate an idea (Corbett 2007). The two ways in which entrepreneurs evaluate an idea are by intuition and by analysis. Corbett (2005) found that there is a direct correlation between intuition and the number of opportunities recognized.

Timmons and Spinelli (2007) in their research find that cognitive processing skills influence opportunity recognition of entrepreneurs. Baron (2004) uses the cognitive principles to explain why individuals become entrepreneurs, identify opportunities and exploit them. There are two ways in which entrepreneurs process their thoughts, namely, by a systematic analysis of the facts and by application of heuristics (Baron 2004). The mistake that entrepreneurs make is by applying heuristics where processing is required and vice versa. This mistake defines the success or the failure of the entrepreneur (Baron 2004). The social networks of the entrepreneur help in combating these errors by providing the entrepreneur with wider information and reliable advice. The different cognitive biases that are predominant among entrepreneurs include overconfidence, illusion of control and representations (use of limited information). The representative bias occurs more when entrepreneurs nest themselves within strong tie networks (De Carolis and Saparito 2006). One should also be aware that cognitive biases not necessarily hinder opportunity recognition but can also promote it to create successful ventures (Adler and Kwon, 2002).

The work of Ornstein in 1977 found that the individuals have two modes of thinking namely intuitive and analytical (Barbosa et al. 2007). Entrepreneurial competencies differ with intuitive and analytical cognitive styles (Vaghely and Julien 2010). This brings us to the research question:

Do different cognitive styles differ in their influence on potential for opportunity recognition along the stages of entrepreneurship? 


\section{Motivation of entrepreneurs}

Shane et al. (2003) extends the domains of entrepreneurs from traits, cognitive abilities and social network to include the indirect effect of motivations in explaining entrepreneurial performance. Given the fact that opportunities exist and an entrepreneur has the required cognition to evaluate and develop them into ventures pushes a series of questions. Is there a drive to recognize the opportunity, drive to evaluate it and a drive to convert it in to a venture?

Murray gave the original theory of needs in 1938, later developed by McClelland (1965). According to the needs theory, any human being is driven by one of the three kinds of motivation, namely need to affiliate, need to achieve and need to be powerful. In the early studies on entrepreneurs, McClelland (1965) did claim the achievement drive as a defining trait of entrepreneurs. However, need for power was an unconscious motives that push entrepreneurs to venture into creating organizations (Hornaday and Aboud, 1971). In addition to being a push factor, it is also are a pull factor. The pull is in terms of positive or negative reinforcement experienced while undertaking the exercise of venture creation (Ellen 2010).

There are motives that individuals exhibit and there are motives that are unconsciously present. The former are explicit motives and latter are the implicit motives (McClelland 1965). Explicit motives help determine the goal setting and goal execution activities whereas the implicit motives target the developmental activities of the individual (McClelland 1965). The motives are influenced by two categories one is the approach (hope) i.e. the desirability of positive experiences and the other is avoidance (fear) i.e. the sensitivity to negative experiences (Sokolowski et al. 2000).

Different entrepreneurs have different needs, varying between achievement and power. Based on the kind of need, an entrepreneur is driven by together with his/her personal and network characteristics it is possible to predict the kind of opportunities, identified and the utility value extracted from them. This brings us to the research question:

\section{Do different needs differ in their influence on potential for opportunity recognition along the stages of entrepreneurship?}

\section{Potential for opportunity recognition: research gaps}

Entrepreneurship research focusing primarily on the firm-performance will not be able to capture the potential gains from the opportunities that were not pursued. Hence, it would be useful to analyze entrepreneurship with a focus on the process of successful opportunity recognition and exploitation (Singh et al. 1999; Shane and Venkataraman 2000).

Due to the constantly changing nature of entrepreneurial activities the elements (or the combination of them) that influence entrepreneurial behavior also change in importance, depending on the activity the entrepreneur would engage with, in the venture creation process. A model to explain the influence of different factors at different phases of entrepreneurship is yet to be created and explored (Shane et al. 2003).

The opportunity recognition is a continuous process that supports the pre-start-up, start-up, survival and growth of a venture and hence it is not a one-time activity in the beginning of venture creation (Singh et al. 1999). However, the kind of opportunity recognized and utilized may differ along the process. Entrepreneurship researches till date have ignored the pre-startup activities by focusing mainly on start-up and growth 
phases. In other words, contemporary research has not studied those individuals who are planning for entrepreneurship though the degree of opportunity recognition potential in those individuals would have a significance influence creation decisions.

Results from the previous studies based on opportunity recognition and traits of entrepreneurs have not been able to fully explain the differences in potential for opportunity recognition across different stages of entrepreneurship. McClelland in 1965 provided evidence that entrepreneurs are achievement motivated individuals and later in 1989 found that entrepreneurs are motivated by power. Hence there were no conclusive results on what motivates the entrepreneurs. Is it the drive to achieve or is it drive to be powerful. Our paper addresses this issue and clarifies that entrepreneurs are motivated by the drive to be powerful and particularly by hope to become powerful and not by the fear of losing power.

There is been a confusion on which kind of social network is useful for entrepreneurs. Whether it is bridging (weak ties) network or is it the bonding (strong ties) network (Bhagavatula et al. 2010). Our paper could identify that both the types of social capital are important for entrepreneurs. The difference is only in the stage in which an entrepreneur is. In other words, it is the experience that the entrepreneur has gained in the process of venture creation, sustenance and growth that decides the kind of network they could create and maintain. As their experience becomes rich, so does there social capital becomes focused on relevant close ties.

We propose to investigate using the frameworks adopted for entrepreneurship research in general. Broadly there are three approaches to entrepreneurship research namely, the behavioral, the social network and the cognitive (Dyer et al. 2008). The present study would adopt these three approaches to understand their influences on opportunity recognition in various stages entrepreneurship. Accordingly the variables used are self-efficacy and motivation (under the behavioral approach), social capital (under the social network approach) and cognitive styles (under the cognitive approach).

Thus, this paper is focused on potential for opportunity recognition of the three stages of entrepreneurship namely, pre-stage, early-stage and late-stage. In each of these stages we will examine the association of opportunity recognition potential the variables mentioned above representing the three approaches to entrepreneurship research. These approaches can be broadly re-classified as personal and interpersonal approaches, the former representing the behavioral and the cognitive and later representing the social network.

\section{Methods}

The next attempt was to identify the factors that affect the potential for opportunity recognition of entrepreneurs in different stages of entrepreneurship. Identification of the factors would help understand how the different activities of entrepreneurs call for different personal and interpersonal factors to support them in their opportunity recognition.

The pre-stage-entrepreneurs engage in opportunity (idea) recognition, business planning and other activities related to preparations to set up a company. They are the would-be entrepreneurs whose success depends on the factors that influence their potential for opportunity recognition (Alvarez and Busenitz 2001). The early-stage-entrepreneur has completed these initial activities and moves into other activities of opportunity 
exploitation for revenues. The late-stage-entrepreneur is capable of all the activities of opportunity recognition and is specifically skilled at exploitation for commercial success.

The potential for opportunity recognition of entrepreneurs in different stages would be influenced by different factors. Literature review (in Section 2) shows that the need for networking in entrepreneurs is common (Singh et al. (1999), Lee and Tsang (2001), Craig and Lindsay (2001) and Ucbasaran et al. (2009)). However, there is a lack of understanding regarding the kind of network they would engage in as their experience becomes richer. Similarly, self-efficacy is also provided with research support in the context of entrepreneurs particularly, because of the nature of an entrepreneur's job, which is consistently varying with the need of the venture (Chen et al. (2001), Barbosa et al. (2007) and McGee et al. (2009)). Allinson and Hayes (1996) gave evidence for change in cognitive styles of entrepreneurs along a continuum of intuitive to analytical. The entrepreneurs with intuitive style would produce break through ides whereas the entrepreneurs with analytical style of cognition will produce only incrementally innovative ideas. McClelland (1965) and Hornaday and Aboud (1971) suggest that the presence of all the three motives, namely affiliation, achievement and power are important for entrepreneurship, irrespective of entrepreneurs being conscious or unconscious of these motives. However, which of them would be dominant as entrepreneurs gain experience is still unexplored.

\section{Hypotheses development}

\section{Pre-stage-entrepreneurs}

The pre-stage-entrepreneurs, as explained earlier, are in the planning stage of the venture creation process and hence, would like to bridge with individuals to get their ideas critically examined by the people known to them, since they are eager to get as much information as possible before they start a venture. They may not create bonding networks in this stage since they may be unable to decide on the people who could support them in the long run for venture creation and development process. In other words, it is too early for them to select the members of their bonding network.

Self-efficacy may be important for entrepreneurs to not only decide to choose entrepreneurship but also in their consistency to progress in venture creation. Many a time individuals begin with ideas but because of lack of confidence in their skills they do not progress further. If their self-efficacy is high they may not discuss their ideas with others and would rely mostly on their abilities to recognize and implement opportunities. However, they will still form networks for support in resources they do not own.

In addition to the networks and self-efficacy, the cognitive styles of entrepreneurs also decide if they would advance into early-stage of entrepreneurship. Adaptive style as described in the literature is a combination of both intuition and analysis. Hence, we expect that in the pre-stage, since the entrepreneurs would want to discuss their ideas and are keen to get reviews from others and also since their experience of entrepreneurship is less they may not rely fully on their own and network member's analysis alone but include it together with their intuition. Hence, the cognitive style that they may adopt would be adaptive.

The kind of motivation that would influence the entrepreneurs in this stage would be dominated by hopes of achievement and power. They may be highly optimistic about 
the success of their ideas as ventures. They may not be motivated by affiliation motivation as in this stage they may have antagonized many of their partners.

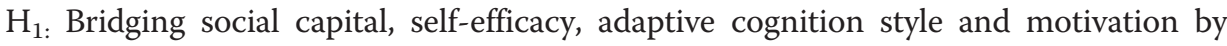
hope influence the potential for opportunity recognition of pre-stage-entrepreneurs.

\section{Early-stage-entrepreneurs}

In the early-stage, the entrepreneurs have some experience of venture creation process and the factors that influence his or her ORP may differ from the entrepreneurs in earlier stage of entrepreneurship, who have no or very little experience and also from the latter kind who have lots of experience. In the early-stage the entrepreneur may want to have both the kind of networks (bridging and bonding) as they play different roles in assisting the entrepreneur in establishing the venture. The bonding networks would help them with emotional support and financial capital whereas the bridging may help with sourcing of new information's and feedbacks.

Self-efficacy may be important in this stage as well, since the confidence in their skills will largely help them in sustaining their venture creation process particularly when they face lots of challenges and hardships, which would be the characteristics of the early-stage-entrepreneurs.

The cognitive style the entrepreneur may use here could be more of analytical, as every decision they make in this stage will influence the existence of the venture. In this stage the entrepreneur is engaged predominantly in formalizing, standardizing and bureaucratization of the enterprise. Though they may want to get feedback and advice from others and would still use their analysis to make venture related decisions.

They are motivated more by fears than by hopes since the setbacks that they have undergone have broken down their optimistic outlook to become more realistic. The overconfidence bias has also been corrected by the harsh realities.

$\mathrm{H}_{2:}$ Bridging and bonding social capital, self-efficacy, analytical cognition style and motivation by fear influence the potential for opportunity recognition of early-stageentrepreneurs.

\section{Late-stage-entrepreneurs}

In the late-stage, the entrepreneur has had enough experience of the entire venture creation process, which may be more than once. Hence, in this stage they have selected and formed their close networks and are more likely to work with them because of the confidence created among them over a period of time.

The self-efficacy may still be important, as it would have increased with experience gained by undergoing and overcoming the challenges in the venture creation. When an individual overcomes tribulations, the happiness of being successful increases confidence in their skills and thus improves their self-efficacy (Bandura, 1986).

Since this study is on the small-scale entrepreneurs whose orientation is not innovation of products, processes or market instead is successful execution to meet the demands, many of them may not use an intuitive style of cognition, which is mostly the style used by high growth entrepreneurs (Allinson et al. 2000). The cognitive style would largely be adaptive since with experience it is assumed that they develop their intuitive skills and would have enough advices based on the analysis of their ties (being among entrepreneurs always) to take decisions based on their adaptive style of cognition. 
Motivation of these entrepreneurs would be more of hopes since they may have overcome the fears and developed confidence in their skills to be able to manage and successfully overcome the hardships associated with venture creation and sustenance.

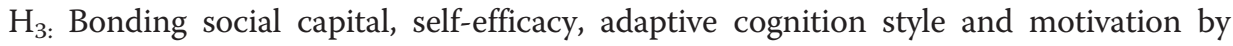
hope influence the potential for opportunity recognition of late-stage entrepreneurs.

\section{Definition and description of the measure for each factor}

The following sections would define the factors and give the description of their measures used in the study.

1. Potential for opportunity recognition (ORP)

13 items of Singh et al. (1999) questionnaire is used, which is anchored on strongly disagree-strongly agree (5 point).

2. Social capital

To measure the bonding and bridging social capital the study uses the social capital scale developed by Williams (2006). The scale has 20 items, 10 to identify the bridging social capital and 10 for bonding social capital with 5-point Likert scale (strongly disagree-strongly agree) for each dimension.

3. Cognitive style

Allinson and Hayes (1996) identify three cognitive styles described as follows:

- Intuitive: Individuals using intuitive cognitive style are defined as the ones who "often experience an immediate sense of knowing which they cannot explain".

- Analytical: Individuals using analyst cognitive style are defined as the ones who "break problems down into their constituent parts and study each part in detail.

- Adaptive: Individuals using adaptive cognitive style are ones who use both intuition and analyst styles for decision making depending upon the situation they are facing.

To measure the cognitive style the study uses the measure of the Cognitive Style Index (CSI) developed by Allinson and Hayes (1996). CSI is an attempt in capturing the varying patterns of thought processes in a unitary scale that is psychometrically sound and overcomes the limitation of several other scales in terms of administration difficulty. It measures the ways in which individuals utilize the information they possess and experiences they have acquired (Corbett 2005).

\section{Self-efficacy}

The Chen's scale is used to measure the general self-efficacy in the study. The scale has 8 items anchored on not at all true-exactly true (5 point).

\section{Motivation}

These two categories of each motive are measured using the Multi Motive Grid (MMG) developed by Sokolowski et al. 2000. It is a measure that combines the features of the questionnaire method with the pictures used in TAT to give a comprehensive scale for assessing all the three motives of an individual and the state of its presence (conscious or unconscious).

Multi-Motive grid comprises 14 picture situations with 12 questions anchored on yesno and generates a score for both the states (hope and fear) for each motive. The highest score decides the driving motive of the individual (Sokolowski et al. 2000). 


\section{Sample for study}

The sampling method used was snowball method in which the business owners were contacted for the responses and then were also asked to give reference for further data collection. The hypotheses were tested using a sample of 279 entrepreneurs with varying industry background.

The data is collected from three sets of entrepreneurs. The first, were potential entrepreneurs who exhibited their interest in an entrepreneurial career by enrolling into an entrepreneurship program (pre-stage or the pre-formation stage also called as the prospective entrepreneurs). These potential entrepreneurs were individuals enrolled for either the two-year program in entrepreneurship or enrolled for electives in entrepreneurship. In the case of early-stage-entrepreneurs, according to Thompson (1999), these entrepreneurs ( 3 to 4 years) fight for their survival. If an entrepreneur successfully overcomes this period and is able to sustain their business, then, he or she is said to be a true entrepreneur. The third sets were entrepreneurs with more than three years of experience (late-stage) with one or more ventures.

The unit of analysis is an entrepreneur, the key responses were that of principal owners who had either started, purchased or inherited the business and were the key decision makers of their establishments. Self-employment was used as a proxy for entrepreneurship. Most of the entrepreneurs are the first generation entrepreneurs (90\%). The survey was conducted from April 2012 to September 2012. 327 responses were obtained which was $31 \%$ return rate of the 1060 distributed questionnaires. The usable questionnaires among the 327 were 255 . The entrepreneur responses collected during the preliminary study (24) was also added to the sample, which increased the total of the data set to 279.

The age of the respondents $(\mathrm{n}=279)$ was in the range of $30-60$ years and $194 \quad(70 \%)$ were male and $85(30 \%)$ were female respondents. Firms on average employed 50 employees. The average number of businesses owned by the sample was 2 . The educational background of the respondents is mostly either bachelors (51\%) or masters (37\%). $59 \%$ of the respondents had work experience and $41 \%$ did not have any work experience. $81 \%$ of the respondents had taken entrepreneurship training and 19\% did not take any entrepreneurship training. The entrepreneurs were from engineering (21\%), manufacturing (19\%), trading (17\%), and services (15\%).

The reliability test for each of the factors influencing potential for opportunity recognition (discussed above) is conducted and the results are given in Tables 1 and 2.

\section{Analyses}

We analyze factors that influence ORP in each stage of entrepreneurship. We verify if any of the factors influence the ORP for each stage separately.

To identify the factors that differed with the stages of entrepreneurship, ANOVA was conducted among the three groups of entrepreneurs. The results are shown in Table 3. The hypotheses were tested using regression analyses shown Tables 4, 5 and 6.

\section{Results}

Relationship between the factors and stages entrepreneurship

The ANOVA test among the three stages of entrepreneurship shows that social capital (bridging and bonding) and motivation by fear (rejection, failure and loss of power) 


\begin{tabular}{|c|c|c|c|c|c|c|}
\hline \multirow{2}{*}{$\begin{array}{l}\text { Description } \\
\text { Age range }\end{array}$} & \multicolumn{2}{|c|}{$\begin{array}{l}\text { Pre-stage } \\
\text { entrepreneurs }(n=118)\end{array}$} & \multicolumn{2}{|c|}{$\begin{array}{l}\text { Early-stage } \\
\text { entrepreneurs ( } n=73 \text { ) }\end{array}$} & \multicolumn{2}{|c|}{$\begin{array}{l}\text { Late-stage } \\
\text { entrepreneurs }(n=88)\end{array}$} \\
\hline & 20-30 years & & $30-50$ years & & $40-60$ years & \\
\hline Gender & Male-72\% & Female-28\% & Male-67\% & Female-33\% & Male-68\% & Female-32\% \\
\hline Education & $\begin{array}{l}\text { Bachelor's } \\
\text { Degree-44\% }\end{array}$ & $\begin{array}{l}\text { Master's } \\
\text { Degree-47\% }\end{array}$ & Bachelors-42\% & Masters-35\% & Bachelors-40\% & Masters-27\% \\
\hline Work experience & Yes-48\% & No-52\% & Yes-84\% & No-16\% & Yes-90\% & No-10\% \\
\hline $\begin{array}{l}\text { Entrepreneurship } \\
\text { training }\end{array}$ & Yes-87\% & No-13\% & Yes-73\% & No-27\% & Yes-84\% & No-16\% \\
\hline \multirow[t]{5}{*}{ Industry by sector } & \multicolumn{2}{|c|}{ Engineering-4\% } & \multicolumn{2}{|c|}{ Engineering-12\% } & \multicolumn{2}{|c|}{ Engineering-27\% } \\
\hline & \multicolumn{2}{|c|}{ Manufacturing-39\% } & \multicolumn{2}{|c|}{ Manufacturing-11\% } & \multicolumn{2}{|c|}{ Manufacturing-25\% } \\
\hline & \multicolumn{2}{|l|}{ Trading-17\% } & \multicolumn{2}{|l|}{ Trading-16\% } & \multicolumn{2}{|l|}{ Trading-17\% } \\
\hline & \multicolumn{2}{|l|}{ Service-13\% } & \multicolumn{2}{|l|}{ Service-18\% } & \multicolumn{2}{|l|}{ Service-12\% } \\
\hline & \multicolumn{2}{|l|}{ Others-27\% } & \multicolumn{2}{|l|}{ Others-43\% } & \multicolumn{2}{|l|}{ Others-19\% } \\
\hline
\end{tabular}

does significantly differ among the three stages of entrepreneurship. To check if there were differences within the groups, three $t$ test analyses were conducted, between pre-stage and early-stage, early-stage and late stage and late-stage and prestage entrepreneurs. The $t$ test showed that pre-stage-entrepreneurs differed from the early-stage-entrepreneurs on bridging social capital, bonding social capital and motivation by fear for failure and fear of loss of power, whereas, early and late-stage did not show any significant difference on any variables. The $t$ test also showed that pre and late-stage-entrepreneurs differed on bridging social capital, bonding social capital, self-efficacy, cognitive style and fear for loss of power. In short, within the group comparison showed that apart from the factors found significant in the ANOVA analysis, self-efficacy differed between the pre-stage and late-stage entrepreneurs. The results are shown in Table 3.

Table 2 Showing the reliability for each factor $(n=279)$

\begin{tabular}{lrr}
\hline Factor & No of items & Cronbach alpha \\
\hline Opportunity recognition potential & 13 & 0.764 \\
Bonding social capital & 10 & 0.800 \\
Bridging social capital & 10 & 0.740 \\
Self-efficacy & 8 & 0.818 \\
Cognitive style & 35 & 0.759 \\
Motivation & No of items & KR $_{20}$ reliability \\
\hline Hope of affiliation & 12 & 0.712 \\
Fear of rejection & 12 & 0.745 \\
Hope of success & 12 & 0.739 \\
Fear of failure & 12 & 0.701 \\
Hope for power & 12 & 0.776 \\
Fear of loss of power & 12 & 0.782 \\
\hline
\end{tabular}


Table 3 Showing ANOVA for pre-stage-entrepreneurs (118), early-stage-entrepreneurs (73) and late-stage-entrepreneurs (88)

\begin{tabular}{lccccccc}
\hline Total & $\begin{array}{c}\text { Pre stage } \\
\mathbf{( 1 )}\end{array}$ & $\begin{array}{c}\text { Early stage } \\
\mathbf{( 2 )}\end{array}$ & $\begin{array}{c}\text { Late stage } \\
\mathbf{( 3 )}\end{array}$ & $\mathbf{F}$ & $\mathbf{t}_{\mathbf{1 - 2}}$ & $\mathbf{t}_{\mathbf{2 - 3}}$ & $\mathbf{t}_{\mathbf{1 - 3}}$ \\
\hline BRSC (bridging social capital) & $27.59(3.62)$ & $26.07(4.05)$ & $25.32(4.18)$ & $9.04^{* *}$ & $2.7^{* *}$ & 1.15 & $4.18^{* *}$ \\
BOSC (bonding social capital) & $27.19(3.73)$ & $25.42(3.94)$ & $26.05(3.72)$ & $5.41^{* *}$ & $3.12^{* *}$ & -1.03 & $2.19^{*}$ \\
SE (self-efficacy) & $27.27(4.19)$ & $26.45(4.23)$ & $25.8(5.67)$ & 2.51 & 1.31 & 0.82 & $2.15^{*}$ \\
CS (cognitive style) & $48.92(7.72)$ & $47.37(9.58)$ & $48(8.9)$ & 0.78 & 1.23 & -0.43 & 0.80 \\
MHA (motivation-hope of affiliation) & $8.99(2.24)$ & $8.68(2.73)$ & $8.58(2.59)$ & 0.77 & 0.85 & 0.25 & 1.2 \\
MFR (motivation-fear of rejection) & $4.26(2.88)$ & $2.63(2.38)$ & $3.02(2.51)$ & $10.24^{* *}$ & $4.06^{* *}$ & 1.01 & $3.22^{* *}$ \\
MHS (motivation-hope of success) & $8.54(2.51)$ & $8.99(2.42)$ & $8.53(2.9)$ & 0.79 & -1.20 & 1.06 & 0.02 \\
MFF (motivation- fear of failure) & $4.53(2.68)$ & $3.44(2.44)$ & $3.81(2.79)$ & $4.24^{* *}$ & 1.84 & 0.88 & 1.89 \\
MHP (motivation- hope for power) & $8.07(2.84)$ & $7.68(2.9)$ & $8.27(3.1)$ & 0.81 & 0.9 & 1.24 & -0.49 \\
MFP (motivation- Fear of loss of & $4.06(2.06)$ & $2.90(2.66)$ & $2.99(2.8)$ & $5.10^{* *}$ & $2.68^{* *}$ & -0.2 & $2.59^{* *}$ \\
power) & & & & & & & \\
\hline
\end{tabular}

${ }^{* *}=\mathrm{p}$ value significant at $0.01,{ }^{*}=\mathrm{p}$ value significant at 0.05

\section{Relationship between the factors and ORP in pre-stage entrepreneurs}

The factors that influence potential for opportunity recognition in pre-stage were examined using regression analyses. The results of regression analysis show that among all the factors bridging social capital, bonding social capital, cognitive style and age influence the ORP of pre-stage-entrepreneurs. The results are shown in Table 4.

The results derived from the regression analysis of pre-stage-entrepreneurs shown in Table 4 follow various explanations found by several scholars. The predominant

Table 4 Showing regression for pre-stage-entrepreneurs (Dependent Variable-Total ORP)

\begin{tabular}{|c|c|c|c|}
\hline & Estimate & Std error & t-value \\
\hline (Constant) & 10.26 & 6.22 & 1.65 \\
\hline BRSC (bridging social capital) & 0.27 & 0.14 & $1.99^{*}$ \\
\hline BOSC (bonding social capital) & 0.31 & 0.15 & $2.02^{*}$ \\
\hline SE (self-efficacy) & 0.11 & 0.13 & 0.84 \\
\hline CS (cognitive style) & 0.34 & 0.07 & $5.08^{* *}$ \\
\hline MHA (motivation-hope of affiliation) & 0.05 & 0.28 & 0.19 \\
\hline MFR (motivation-fear of rejection) & 0.17 & 0.27 & 0.65 \\
\hline MHS (motivation-hope of success) & 0.19 & 0.26 & 0.73 \\
\hline MFF (motivation- fear of failure) & -0.29 & 0.27 & -1.08 \\
\hline MHP (motivation- hope for power) & 0.23 & 0.20 & 1.17 \\
\hline MFP (motivation- fear of loss of power) & -0.18 & 0.25 & -0.72 \\
\hline Gender & 1.12 & 1.22 & 0.91 \\
\hline Work Experience & -0.53 & 1.07 & -0.49 \\
\hline Age & 7.92 & 3.81 & $2.08^{*}$ \\
\hline Education & 2.75 & 3.40 & 0.81 \\
\hline Entrepreneurship training & 0.48 & 1.76 & 0.27 \\
\hline N & R square & Adjusted R square & F-value \\
\hline 118 & 0.548 & 0.455 & $5.920^{* *}$ \\
\hline
\end{tabular}

${ }^{* *}=\mathrm{p}$ value significant at $0.01,{ }^{*}=\mathrm{p}$ value significant at 0.05 .

The estimates are significant for four variables namely Bridging social capital (BRSC), Bonding social capital (BOSC), Cognitive style (CS) and Age. 
Table 5 Showing regression for early-stage-entrepreneurs (Dependent Variable-Total ORP)

\begin{tabular}{|c|c|c|c|}
\hline & Estimate & Std error & t-value \\
\hline (Constant) & 27.23 & 7.97 & $3.42^{* *}$ \\
\hline BRSC (bridging social capital) & 0.24 & 0.20 & 1.15 \\
\hline BOSC (bonding social capital) & 0.48 & 0.21 & $2.31^{*}$ \\
\hline SE (self-efficacy) & -0.24 & 0.24 & -1.03 \\
\hline CS (cognitive style) & 0.17 & 0.07 & $2.41^{*}$ \\
\hline MHA (motivation-hope of affiliation) & 0.02 & 0.30 & 0.07 \\
\hline MFR (motivation-fear of rejection) & -0.11 & 0.39 & -0.27 \\
\hline MHS (motivation-hope of success) & -0.51 & 0.35 & -1.47 \\
\hline MFF (motivation- fear of failure) & 0.30 & 0.38 & 0.79 \\
\hline MHP (motivation- hope for power) & 0.18 & 0.30 & 0.60 \\
\hline MFP (motivation- fear of loss of power) & -0.34 & 0.37 & -0.92 \\
\hline Gender & 4.01 & 1.46 & $2.75^{* *}$ \\
\hline Work experience & 0.27 & 1.87 & 0.14 \\
\hline Age & 1.30 & 1.77 & 0.74 \\
\hline Education & 3.47 & 2.87 & 1.21 \\
\hline Entrepreneurship training & -0.35 & 1.85 & -0.19 \\
\hline N & $\mathrm{R}$ square & Adjusted R square & F-value \\
\hline 73 & 0.523 & 0.312 & $2.483^{* *}$ \\
\hline
\end{tabular}

${ }^{* *}=\mathrm{p}$ value significant at $0.01,{ }^{*}=\mathrm{p}$ value significant at 0.05 .

The estimates are significant for three variables namely Bonding social capital (BOSC), Cognitive style (CS) And Gender.

Table 6 Showing regression for late-stage-entrepreneurs (Dependent Variable-Total ORP)

\begin{tabular}{|c|c|c|c|}
\hline & Estimate & Std error & t-value \\
\hline (Constant) & 25.85 & 7.13 & $3.63^{* *}$ \\
\hline BRSC (bridging social capital) & 0.03 & 0.16 & 0.71 \\
\hline BOSC (bonding social capital) & 0.85 & 0.23 & $3.67^{* *}$ \\
\hline SE (self-efficacy) & -0.12 & 0.12 & -0.96 \\
\hline CS (cognitive style) & 0.12 & 0.08 & 1.45 \\
\hline MHA (motivation-hope of affiliation) & 0.26 & 0.41 & 0.63 \\
\hline MFR (motivation-fear of rejection) & -0.22 & 0.33 & -0.60 \\
\hline MHS (motivation-hope of success) & 0.35 & 0.37 & 0.88 \\
\hline MFF (motivation- fear of failure) & -0.04 & 0.32 & -0.12 \\
\hline MHP (motivation- hope for power) & -0.78 & 0.39 & $-3.35^{* *}$ \\
\hline MFP (motivation- fear of loss of power) & 0.25 & 0.23 & 0.76 \\
\hline Gender & -1.14 & 1.58 & -0.72 \\
\hline Work experience & -1.42 & 2.05 & -0.69 \\
\hline Age & 4.16 & 1.86 & $2.23^{*}$ \\
\hline Education & 2.55 & 2.44 & 1.05 \\
\hline Entrepreneurship training & 1.71 & 1.84 & 0.93 \\
\hline N & R square & Adjusted R square & F-value \\
\hline 88 & 0.640 & 0.503 & $4.681^{* *}$ \\
\hline
\end{tabular}

${ }^{* *}=\mathrm{p}$ value significant at $0.01,{ }^{*}=\mathrm{p}$ value significant at 0.05 .

The estimates are significant for three variables namely Bonding social capital (BOSC), Motivation by hope for power (MHP) and Age. 
activities of the pre-stage-entrepreneurs are developing opportunity confidence and early planning actions, which includes accessing their resources required for venturing, market acceptance of their products or services and competition from existing products and technology (Dimov 2010). To undertake the activities mentioned above these entrepreneurs need access to reliable and wide information that they sought from their networks (Liao and Welsch 2003). The entrepreneurs in this stage are not only exploring their existing ties but are also creating new ties to identify the network that would support them in the venturing activity (Honig and Davidsson 2000).

Also the pre-stage-entrepreneur's ideas may face liability of newness (Johannisson 2000), which he or she may not be able to resolve. The social network members support the entrepreneur to overcome it. Pre-stage-entrepreneurs start with over optimistic expectations of the performance of their ideas, which can blur their decision-making (Cassar 2010). The social network members would give them an outsiders view (unbiased) to their venture creation idea evaluation and implementation. Some individual are unaware of their potential to become entrepreneurs. It was also noted by Zanakis et al. (2012) that sometimes it is the social ties that persuade an individual to become an entrepreneur. Thus social networks play varied and immensely important role for pre-stage-entrepreneurs.

Cognitive style influences the ORP of the pre-stage-entrepreneurs by affecting their intention to start, search behavior and ability to find relationships between the unrelated occurrences (Krueger and Kickul 2011; Baron 2006). Irrespective of the cognitive style the entrepreneur uses, it is the role that cognition plays in intention to recognize and implement venture creation ideas.

The self-efficacy did not influence ORP of pre-stage-entrepreneurs because the entrepreneurs start with the perception of having control of environment (Hayek, 2012) and so their self-efficacy plays a very little role in their opportunity recognition process. The motivation also seems to be less important since it influences quitting venture decisions than starting venture decisions (Hechavarria et al. 2012). Age has significant influence on ORP with lower age group of pre-stage-entrepreneurs seem to have better ORP that the higher age group. This follows the understanding that age is different from experience. The pre-stage-entrepreneurs could be in the age group of 40 to 50 years and in the age group of 20 to 30 years. The difference in the experience between the two age groups would influence their ORP.

\section{Relationship between the factors and ORP in early-stage-entrepreneurs}

The factors that were found to influence the ORP of early-stage-entrepreneurs were bonding social capital, cognitive style and gender. The results are shown in Table 5.

The finding that bonding social capital was important to increase potential for opportunity recognition of early stage entrepreneurs is in line with the Mosey and Wright (2007) research which states that broader networks will narrow down with entrepreneurship experience. In the pre-stage we found that bridging and bonding (both) social capital influenced ORP but this was reduced to only bonding social capital in the early-stage. This indicated that with experience the entrepreneur narrowed down his/her network to relevant ties and convert than into bonding relationships, maintaining fewer strong ties.

According to Carland et al. (1996), entrepreneurial process depends on the decisions that entrepreneurs take, which to a large extend is influenced by the style with which 
they think. Again the research of Armstrong and Hird (2009) define the nature of early-stage-entrepreneurs as dealing with 'uncertainty and ambiguous' situations and thus the entrepreneurs in this stage are naturally very analytical in all their approaches in order to be careful in their decision-making. Early-stage-entrepreneurs face lots of challenges and setbacks that they tend to become more prone to rely on analysis for most of their actions. The level of risk is also very high. The entrepreneur in this stage aims at managing the risk by taking decisions that logically look to be beneficial to him or her. With years of experience in using analysis, they may develop an intuition of what decisions could be good and what could hurt the business.

Two third (67\%) of the early-stage entrepreneurs are males which is in line with the studies done on influence of gender on entrepreneur performance. It is noted that women in general are less motivated to choose an entrepreneurial venture because the lack of access to resources imposed by the systems makes it difficult for them to pursue entrepreneurship (Fischer et al. (1993); Bruni et al. (2004)).

\section{Relationship between the factors and ORP in late-stage-entrepreneurs}

The analysis of late-stage-entrepreneurs shows that bonding social capital, motivation by hope for power and age influences their ORP. The results are shown in Table 6 .

The finding that bonding social capital influences the ORP of late-stage entrepreneurs as it did for early-stage confirms with the findings of Greve and Salaff (2003). In their research they provided evidence that experienced entrepreneurs and novice (in this case early-stage) entrepreneurs would tend to have similar type of networks. This is because in the early-stage the entrepreneurs have created their close networks and would hesitate to move away from these reliable ties. As early-stage and late-stage entrepreneurs acquire more experience they bridge less.

The entrepreneurs in this stage are driven by hope for power since they have already achieved their goals, which is evident by the venture sustenance and growth. McClelland et al. (1989) did emphasize that power motives are drivers of entrepreneur performance than the achievement motives.

A multi co-linearity diagnosis of the factors for each stage was conducted and VIF (variance inflation factors) values were found to be greater than 1 for all the variables in the three stages. This meant that there was no correlation among the variables.

\section{Discussions and suggestions}

\section{Social capital and stages of entrepreneurship}

The hypothesis $\mathrm{H}_{1}$ stating that bridging social capital influences the ORP of pre-stageentrepreneurs than the bonding social capital was not supported. Also hypothesis $\mathrm{H}_{2}$ stating both the types of social capital influence ORP of early-stage-entrepreneurs was not supported. Further, the hypothesis $\mathrm{H}_{3}$ stating that bonding social capital and not the bridging social capital influence the ORP of late-stage entrepreneur was supported. These results indicate that both the forms of social capital were important for ORP of pre-stage-entrepreneurs, and bonding social capital was found to influence ORP of early-stage and late-stage-entrepreneurs. This was also established in Newbert et al. (2013) study that pre-stage-entrepreneurs would tend to have both the types of social capital to help them evolve their organization. 


\section{Self-efficacy and stages of entrepreneurship}

The hypotheses, $\mathrm{H}_{1}$ stating that self-efficacy would influence the ORP of prestage-entrepreneurs, $\mathrm{H}_{2}$ stating that self-efficacy would influence the ORP of earlystage-entrepreneurs and $\mathrm{H}_{3}$ stating that self-efficacy would influence the ORP of late-stage-entrepreneurs were not supported. These results suggested that selfefficacy of entrepreneurs was not found to influence their ORP in any stage of entrepreneurship (pre, early and late-stage). This is because all the entrepreneurs had high scores for self-efficacy (27 from a total of 40 ). The researchers in future can explore the reasons behind this observation.

\section{CS and stages of entrepreneurship}

The hypotheses, $\mathrm{H}_{1}$ stating that adaptive style of cognition was associated with the ORP of pre-stage-entrepreneurs and $\mathrm{H}_{2}$ stating that analytical style was associated with ORP of early-stage-entrepreneurs was not supported. $\mathrm{H}_{3}$ stating that adaptive style was associated with the ORP of late-stage-entrepreneurs was not supported; cognitive style was found to influence ORP of entrepreneurs in all the stages, however, there was no significant influence for late-stage-entrepreneurs. It is possible that late-stageentrepreneurs were more intuitive. The break-up is in Table 7 and Figure 1.

\section{Motivation and stages of entrepreneurship}

The hypothesis $\mathrm{H}_{1}$ stating that motivation by hope (success and power) would influence ORP of pre-stage-entrepreneurship and $\mathrm{H}_{2}$ stating that motivation by fear (failure and loss of power) were not supported, motivation by hope nor by fear influenced the ORP of pre and early-stage-entrepreneurs, but hypothesis $\mathrm{H}_{3}$ stating that motivation by hope (success and power) would influence ORP of late-stage-entrepreneurs was partially not supported, the late-stage entrepreneur's ORP was influenced by their motivation by hope for power.

\section{Demographic variables and stages of entrepreneurship}

Among the demographic factors, age influenced the ORP of pre and late-stageentrepreneurs whereas gender influenced the ORP of early-stage-entrepreneurs.

\section{Conclusion}

The factors that influence ORP of entrepreneurs in their stages the results revealed that entrepreneurs in all the stages had bonding social capital influencing their potential for opportunity recognition. This result can be explained from the fact that entrepreneurs tap on close relationships than the weak ones. Since the decisions that they take are so crucial for their businesses, they cannot risk relying on passing suggestions. It is also

Table 7 Showing the cognitive style for each stage of entrepreneurship

\begin{tabular}{lrrrrrr}
\hline CS & & Pre stage & & Early-stage & Late-stage \\
\hline & $\mathrm{N}$ & $\%$ & $\mathrm{~N}$ & $\%$ & $\mathrm{~N}$ & $\%$ \\
Intuitive & 4 & $3.4 \%$ & 4 & $5.5 \%$ & 3 & $3.4 \%$ \\
Adaptive & 35 & $29.7 \%$ & 25 & $34.2 \%$ & 34 & $38.6 \%$ \\
Analyst & 79 & $66.9 \%$ & 44 & $60.3 \%$ & 51 & $58.0 \%$ \\
Total & 118 & $100.0 \%$ & 73 & $100.0 \%$ & 88 & $100.0 \%$ \\
\hline
\end{tabular}




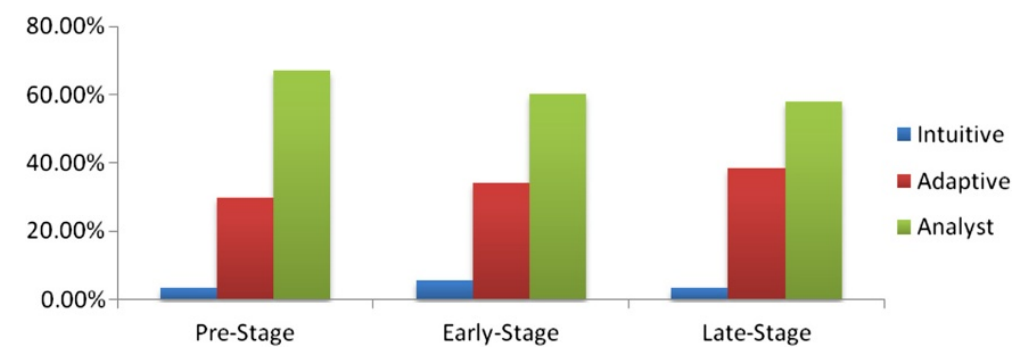

Figure 1 Showing the CS for each stage of entrepreneurship.

possible that the entrepreneurs would convert the relevant weak ties into strong ties so that the close and consistent relationships could be trusted and utilized as a support for the venture.

The research of Simoni and Labory (2007) show that the potential entrepreneurs would converse more with their close group networks for opportunity recognition, which is also, true about experienced entrepreneurs who would have only limited relevant group for discussion of venture formation issues. Also, non-experienced entrepreneurs would develop ties with experienced entrepreneurs (Ucbasaran et al. 2009). The experienced entrepreneurs dependent more on strong ties than weak ties as it affects their venture progress (Hoang and Antoncic 2003). Due to the presence of liability of newness and smallness in the firms, entrepreneurs need more social capital to lead their firms to growth (Johannisson 2000). Gemeinschaft (closer relation with family members and friends) is more important than the Gesellschaft (closer relations with new contacts) for entrepreneurs to identify and exploit opportunities (Marti et al. 2013).

In addition to the above, discussed reasons bonding social capital for the entrepreneurs has an important role in exploitation of the opportunity since they provide financial resource required for implementation of ideas.

The bridging social capital was found to influence the potential for opportunity recognition only for pre-stage-entrepreneurs. At this stage the potential entrepreneur has not decided who would be relevant to their venture and which of the ties should be maintained for support in business. Hence, they create contacts with every individual they meet but by the time the entrepreneur has formed the venture they are able to restrict themselves to the closer relevant ties (Honig and Davidsson 2000). This could be the reason for bridging social capital affecting opportunity recognition only in the prestage and not in the early and late-stages of entrepreneurship.

The cognitive style influences the potential for opportunity recognition of pre-stageentrepreneurs and early-stage-entrepreneurs. The pre and early-stage-entrepreneurs use analytical style of cognition since the entrepreneur's focus is more on the evaluation of ideas in case of the former stage and implementation of ideas for the latter stage. The pre-stage-entrepreneur may rely on the evaluation by their social networks (bridging and bonding) whereas the early-stage-entrepreneur uses analytical approach to check the feasibility of implementation options and selects the most suitable ones amongst their available resources.

In late-stage the cognitive style does not influence the potential for opportunity recognition since the objective of the entrepreneur is to grow the venture and hence the 


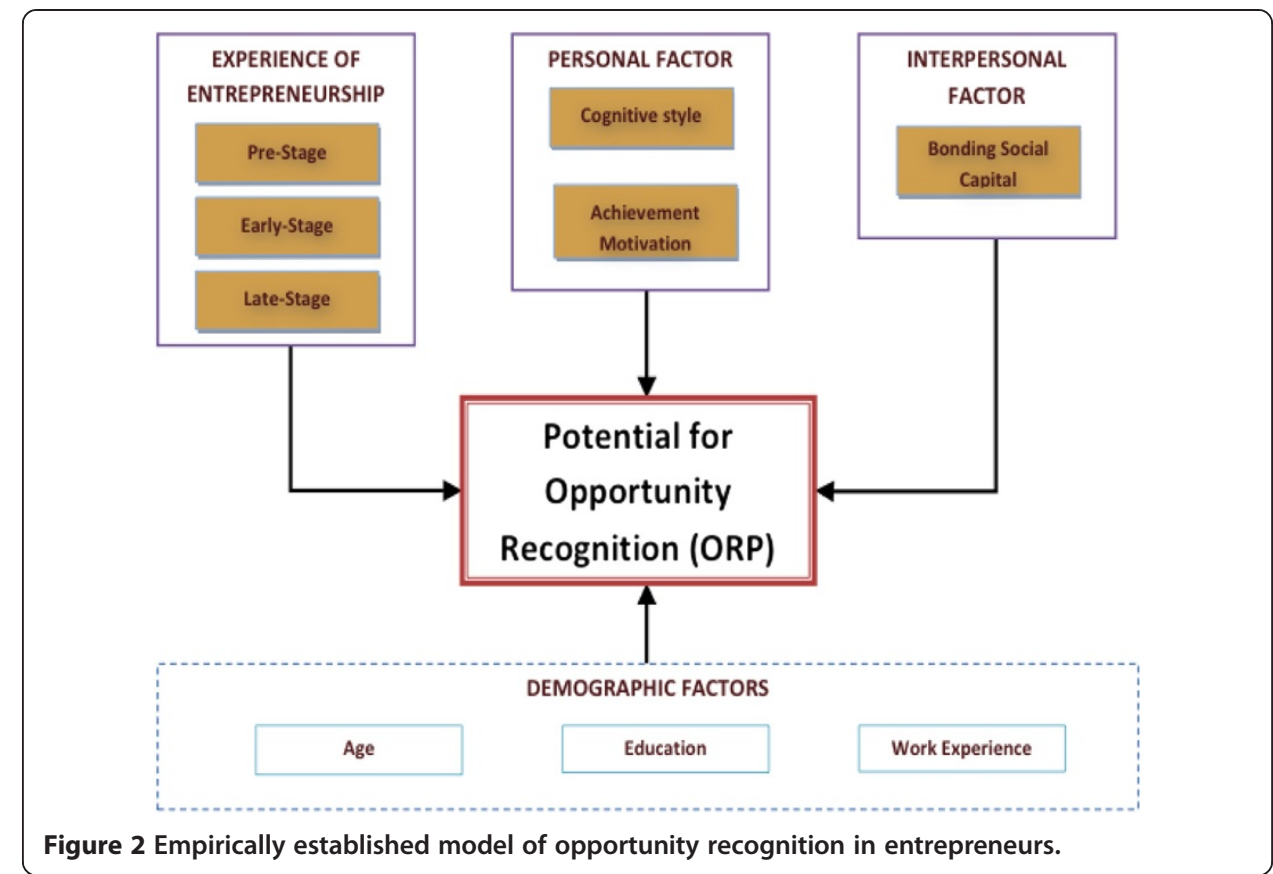

most appropriate style they might use would be intuitive. However, we do not have sufficient samples with the intuitive cognitive style and this finding is not empirically conclusive in this study.

Self-efficacy and motivation factors were not found to influence the ORP in any stage of entrepreneurs. It was only the social capital and cognitive style that influenced ORP of entrepreneurs in different stages. The self-efficacy of entrepreneurs was found to be high for all the three stages (greater than 25). Motivation is believed to largely influence quit decisions than the start decisions (Hechavarria et al. 2012).

Among the demographic variables that were tested age and gender were found to influence ORP. In the pre and late-stage, age was important for opportunity recognition. The kind of opportunities recognized would be different with increase in the age. Bates (1995) provided evidence that with the increase in age of the entrepreneur his or her skills to perform also improve which might be true with opportunity recognition. The gender was important for entrepreneur in the early-stage, which is defined by organizing of resources for venture development.

A diagrammatic representation of the above relationships is shown in Figure 2.

Competing interests

The authors declare that they have no competing interest.

Authors' contributions

KPW carried out the entire research process that includes literature review, data collection and analysis and discussion of the findings. MM provided advisory support through out the process and reviewed the final outcome. Both the authors read and approved the final manuscript.

Acknowledgements

The authors thank each and every entrepreneur for their response and support in the study.

Author details

${ }^{1}$ Department of Management Studies, Indian Institute of Science, Bangalore 560012, India. ${ }^{2}$ Department of Management Studies, Indian Institute of Science, Bangalore 560012, India. ${ }^{3}$ Centre for Product Design and Manufacturing, Indian Institute of Science, Bangalore 560012, India. ${ }^{4}$ Society for Innovation Development, Indian 
Institute of Science, Bangalore 560012, India. Intellectual Property Cell, Indian Institute of Science, Bangalore 560012, India.

Received: 11 October 2013 Accepted: 9 April 2014 Published: 13 May 2014

\section{References}

Adler, PS \& Kwon, SW. (2002). Social capital: Prospects for a new concept. Academy of management review, 27(1), 17-40. Allinson, CW, Chell, E, \& Hayes, J. (2000). Intuition and entrepreneurial behavior. European Journal of Work and Organizational Psychology, 9(1), 31-43.

Allinson, CW, \& Hayes, J. (1996). The Cognitive Style Index: A measure of intuition-analysis for organisational research. Journal of Management Studies, 33(1), 119-135.

Alvarez, SA, \& Barney, JB. (2000). Entrepreneurial capabilities: A resource-based view. In GD Meyer \& KA Heppard (Eds.), Entrepreneurship as Strategy: Competing on the entrepreneurial edge (pp. 63-82). Thousand Oaks: Sage Publications.

Alvarez, S, \& Barney, J. (2007). Discovery and creation: Alternative theories of entrepreneurial action. Strategic Entrepreneurship Journal, 1, 11-26.

Alvarez, SA, \& Barney, JB. (2013). Epistemology, opportunities, and entrepreneurship: Comments on Venkataraman et al. (2012) and Shane (2012). Academy of Management Review, 38, 154-157.

Alvarez, S, \& Busenitz, L. (2001). The entrepreneurship of resource-based theory. Journal of Management, 6, 755-775.

Ardichvili, A, Cardoza, R, \& Ray, S. (2003). A theory of entrepreneurial opportunity identification and development. Journal of Business Venturing, 18, 105-123.

Armstrong, SJ, \& Hird, A. (2009). Cognitive style and entrepreneurial drive of new and mature business ownermanagers. Journal of Business and Psychology, 24(4), 419-430.

Bandura, A. (1986). Social foundations of thought and action: A social cognitive theory. Englewood Cliffs, NJ: Prentice-Hall.

Bandura, A. (1993). Perceived self-efficacy in cognitive development and functioning. Educational Psychologist, 28(2), $117-148$.

Barbosa, SD, Gerhardt, MW, \& Kickul, JR. (2007). The role of cognitive style and risk preference on entrepreneurial selfefficacy and entrepreneurial intentions. Journal of Leadership \& Organizational Studies, 13(4), 86-104.

Baron, RA. (2002). OB and entrepreneurship: the reciprocal benefits of closer conceptual links. In BM Staw \& R Kramer (Eds.), Research in Organizational Behavior (pp. 225-269). Greenwich, CT: JAI Press.

Baron, RA. (2004). The cognitive perspective: a valuable tool for answering entrepreneurship's basic "why" questions. Journal of Business Venturing, 19(2), 221-239.

Baron, RA, \& Ensley, MD. (2006). Opportunity recognition as the detection of meaningful patterns: Evidence from comparisons of novice and experienced entrepreneurs. Management Science, 52(9), 1331-1344.

Bates, T. (1995). Self-employment entry across industry groups. Journal of Business Venturing, 10(2), 143-156.

Bhagavatula, S, Elfring, T, Tilburg, A, \& Van de Bunt, GG. (2010). How social and human capital influence opportunity recognition and resource mobilization in India's handloom industry? Journal of Business Venturing, 25(3), 245-260.

Bhave, MP. (1994). A process model of entrepreneurial venture creation. Journal of Business Venturing, 9(3), 223-242.

Bruner, J. (1990). Culture and human development: A new look. Human Development, 33, 344-355.

Bruni, A, Gherardi, S, \& Poggio, B. (2004). Entrepreneur-mentality, gender and the study of women entrepreneurs. Journal of Organizational Change Management, 17(3), 256-268.

Burt, RS. (1997). The contingent value of social capital. Administrative Science Quarterly, 42, 339-365.

Carland, JW, Carland, JA, \& Stewart, WH. (1996). Seeing what's not there: The enigma of entrepreneurship. Journal of Small Business Strategy, 7, 1-20.

Cassar, G. (2010). Are individuals entering self-employment overly optimistic? an empirical test of plans and projections on nascent entrepreneur expectations. Strategic Management Journal, 31(8), 822-840.

Chen, CC, Greene, PG, \& Crick, A. (1998). Does entrepreneurial self-efficacy distinguish entrepreneurs from managers? Journal of Business Venturing, 13, 295-316.

Chen, G, Gully, SM, \& Eden, D. (2001). Validation of a new general self-efficacy scale. Organizational research methods, $4(1), 62-83$.

Christensen, PS, Madsen, OO, \& Peterson, R. (1989). Opportunity Identification: The Contribution of Entrepreneurship to Strategic Management. Denmark: Aarhus University Institute of Management.

Corbett, AC. (2005). Experiential learning within the process of opportunity identification and exploitation. Entrepreneurship: Theory and Practice, 29(4), 473-491.

Corbett, AC. (2007). Learning asymmetries and the discovery of entrepreneurial opportunities. Journal of Business Venturing, 22(1), 97-118.

Craig, J, \& Lindsay, N. (2001). Quantifying 'gut feeling' in the opportunity recognition process (Frontiers of Entrepreneurship Research, pp. 1-9). Wellesley, MA: Babson College.

Davidson, D. (2001). Subjective, intersubjective, objective. New York: Oxford University Press.

De Carolis, D, \& Saparito, P. (2006). Social capital, cognition, and entrepreneurial opportunities: a theoretical framework. Entrepreneurship: Theory \& Practice, 30(1), 41-56.

De Koning, A. (1999). Conceptualizing opportunity recognition as a socio-cognitive process. Stockholm: Centre for Advanced Studies in Leadership.

deBono, E. (1978). When Opportunity Knocks. Management Today (September), 102-105.

DeTienne, D. (2010). Entrepreneurial exit as a critical component of the entrepreneurial process: Theoretical development. Journal of Business Venturing, 25, 203-215.

Dimov, D. (2007). Beyond the single-person, single-insight attribution in understanding entrepreneurial opportunities. Entrepreneurship Theory and Practice, 31(5), 713-731.

Dimov, D. (2010). Nascent entrepreneurs and venture emergence: opportunity confidence, human capital, and early planning. Journal of Management Studies, 47(6), 1123-1153. 
Dyer, JH, Gregersen, HB, \& Christensen, C. (2008). Entrepreneur behaviors, opportunity recognition, and the origins of innovative ventures. Strategic Entrepreneurship Journal, 2(4), 317-338.

Egbert, H. (2009). Business success through social networks? a comment on social networks and business success. American Journal of Economics \& Sociology, 68(3), 665-677.

Ellen, A. (2010). Entrepreneurial Intentions of Business Students in Finland: Implications for Education. Advances in Management, 3(7), 28-35.

Fischer, EM, Reuber, AR, \& Dyke, LS. (1993). A theoretical overview and extension of research on sex, gender, and entrepreneurship. Journal of Business Venturing, 8(2), 151-168.

Gartner, W. (1990). What are we talking about when we talk about entrepreneurship?". Journal of Business Venturing, 5(1), 15-28.

Gartner, WB, Bird, B, \& Starr, J. (1992). Acting as if: differentiating entrepreneurial from organizational behavior. Entrepreneurship: Theory \& Practice, 16(3), 13-31.

Garud, R, \& Karnøe, P. (2003). Bricolage vs. breakthrough: Distributed and embedded agency in technology entrepreneurship. Research Policy, 32, 277-300.

Greve, A, \& Salaff, JW. (2003). Social networks and entrepreneurship. Entrepreneurship: Theory and Practice, 28, 1-22.

Guard, R, \& Giuliani, AP. (2013). A narrative perspective on entrepreneurial opportunities. Academy of Management Review, 38, 157-160.

Hayek, M. (2012). Control beliefs and positive psychological capital: can nascent entrepreneurs discriminate between what can and cannot be controlled? Journal of Management Research, 12(1), 3-13.

Hechavarria, D, Renko, M, \& Matthews, C. (2012). The nascent entrepreneurship hub: goals, entrepreneurial self-efficacy and start-up outcomes. Small Business Economics, 39(3), 685-701.

Hills, GE, Hansen, DJ, \& Hultman, C. (2004). Opportunity recognition processes: A value creation context (Working Papers of Institute for Entrepreneurial Studies, pp. 1-13). Chicago: University of Illinois.

Hoang, H, \& Antoncic, B. (2003). Network-based research in entrepreneurship: A critical review. Journal of Business Venturing, 18, 165-187.

Honig, B, \& Davidsson, P. (2000). The role of social and human capital among nascent entrepreneurs. In Academy of Management Proceedings (Vol. 2000, No. 1, pp. B1-B6). Academy of Management.

Hornaday, JA, \& Aboud, J. (1971). Characteristics of successful entrepreneurs. Personnel Psychology, 24, 141-153.

Hulbert, B, Brown, RB, \& Adams, S. (1997). Towards an understanding of" opportunity". Marketing Education Review, 7(3), 67-73.

Johannisson, B. (2000). Networking and Entrepreneurial Growth. In DL Sexton \& H Landstrom (Eds.), The Backwell Handbook of Entrepreneurship. Oxford: Blackwell.

Kirzner, I. (1997). Entrepreneurial discovery and the competitive market process: An Austrian approach. Journal of Economic Literature, 35, 60-85.

Klein, P. (2008). Opportunity discovery, opportunity exploitation, and economic organization. Strategic Entrepreneurship Journal, 2, 175-190.

Korunka, C, Frank, H, Lueger, M, \& Mugier, J. (2003). The Entrepreneurial Personality in the Context of resources, environment, and the startup process - A configurational approach. Entrepreneurship Theory \& Practice, 28, 23-42.

Krueger, N, Jr. (2003). The cognitive psychology of entrepreneurship. In ZA Acs \& DB Audretsch (Eds.), Handbook of Entrepreneurial Research (pp. 105-140). London: Kluwer Law International.

Krueger, N, Jr, Brazeal, \& Deborah, V. (1994). Entrepreneurial potential and potential entrepreneurs. Entrepreneurship: Theory and Practice, 18(3), 91-104.

Krueger, NF, \& Kickul, J. (2011). Cognitive style and the specification of entrepreneurial intentions models (Neuropsychoeconomics Conference Proceedings, p. 22).

Lee, D, \& Tsang, E. (2001). The effects of entrepreneurial personality, background and network activity on venture growth. Journal of Management Studies, 38, 583-602. Lucas.

Liao, J, \& Welsch, H. (2003). Social capital and entrepreneurial growth aspiration: a comparison of technology- and nontechnology-based nascent entrepreneurs. Journal of High Technology Management Research, 14(1), 149.

Long, W, \& McMullan, WE. (1984). Mapping the New Venture Opportunity Identification Process. In JA Hornaday et al. (Eds.), Frontiers of Entrepreneurship Research (pp. 567-590). Wellesley, MA: Babson College.

Lumpkin, GT, \& Lichtenstein, BB. (2005). The role of organizational learning in the opportunity recognition process. Entrepreneurship: Theory and Practice, 29(4), 451-472.

Marti, I, Courpasson, D, \& Dubard Barbosa, S. (2013). Living in the fishbowl". Generating an entrepreneurial culture in a local community in Argentina. Journal of Business Venturing, 28(1), 10-29.

McClelland, DC. (1965). Toward a theory of motive acquisition. American Psychologist, 20, 321-333.

McClelland, DC, Koestner, R, \& Weinberger, J. (1989). How do self-attributed and implicit motives differ? Psychological Review, 96(4), 690

McGee, JE, Peterson, M, Mueller, SL, \& Sequeira, JM. (2009). Entrepreneurial self-efficacy: refining the measure. Entrepreneurship: Theory \& Practice, 33(4), 965-988.

Mitchell, RK, Busenitz, L, Lant, T, McDougall, PP, Morse, EA, \& Smith, J. (2004). The distinctive and inclusive domain of entrepreneurial cognition research. Entrepreneurship: Theory and Practice, 28(6), 505-518.

Mosey, S, \& Wright, M. (2007). From human capital to social capital: a longitudinal study of technology-based academic entrepreneurs. Entrepreneurship: Theory and Practice, 31, 909-935.

Nahapiet, J, \& Ghoshal, S. (1998). Social capital, intellectual capital, and the organizational advantage. The Academy of Management Review, 23(2), 242-266.

Newbert, SL, Tornikoski, ET, \& Quigley, NR. (2013). Exploring the evolution of supporter networks in the creation of new organizations. Journal of Business Venturing, 28(2), 281-298.

Nicolaou, N, Shane, S, Cherkas, L, \& Spector, TD. (2009). Opportunity recognition and the tendency to be an entrepreneur: A bivariate genetics perspective". Organizational Behavior and Human Decision Processes, 110, 108-117.

Putnam, RD. (1995). Tuning in, tuning out: The strange disappearance of social capital in America. PS: Political Science \& Politics, 28(04), 664-683.

Reynolds, PD, \& White, SB. (1997). The entrepreneurial process: Economic growth, men, women, and minorities. Westport, CT: Quorum Books. 
Sambasivan, M, Abdul, M, \& Yusop, Y. (2009). Impact of personal qualities and management skills of entrepreneurs on venture performance in Malaysia: Opportunity recognition skills as a mediating factor. Technovation, 29(11), 798 .

Santos, FM, \& Eisenhardt, KM. (2005). Organizational boundaries and theories of organization. Organization science, 16(5), 491-508.

Sarason, Y, Dean, T, \& Dillard, J. (2006). Entrepreneurship as the nexus of individual and opportunity: a structuration view. Journal of Business Venturing, 21, 285-305.

Sarasvathy, S. (2001). Causation and effectuation: Toward a theoretical shift from economic inevitability to entrepreneurial contingency. Academy of Management Review, 26, 243-263.

Sarasvathy, SD, \& Dew, N. (2005). New market creation through transformation. Journal of Evolutionary Economics, 15(5), $533-565$.

Shane, S. (2012). Reflections on the 2010 AMR Decade Award: delivering on the promise of entrepreneurship as a field of research. Academy of Management Review, 37, 10-20.

Shane, S, Locke, EA, \& Collins, CJ. (2003). Entrepreneurial motivation. Human Resource Management Review, 13, 257-279.

Shane, S, \& Venkataraman, S. (2000). The promise of entrepreneurship as a field of research. Academy of Management Review, 25(1), 217-226.

Short, JC, Ketchen, DJ, Shook, CL, \& Ireland, RD. (2010). The concept of "opportunity" in entrepreneurship research: Past accomplishments and future challenges. Journal of Management, 36(1), 40-65.

Simoni, C, \& Labory, S. (2007). The influence of Social Capital on Entrepreneurial Behavior. In A Zacharakis, M Minniti, S Spinelli, MP Rice, \& TG Habbershon (Eds.), Entrepreneurship: The Engine of Growth (Volume 1) (pp. 1-20). Westport, CT: Greenwood Publishing Group.

Singh, RP, Hills, GE, Lumpkin, GT, \& Hybels, CR. (1999). The entrepreneur opportunity recognition process: Examining the role of self perceived alertness and social networks. Chicago, Illinois: Academy of Management Proceedings.

Sokolowski, K, Schmalt, HD, Langens, TA, \& Puca, RM. (2000). Assessing achievement, affiliation, and power motives all at once: the Multi-Motive Grid (MMG). Journal of Personality Assessment, 74, 126-145.

Stevenson, HH. (1983). A perspective on entrepreneurship. Harvard Business School Working Paper No. 9-384-131. Boston: Harvard Business School.

Thompson, JL. (1999). A strategic perspective of entrepreneurship. International Journal of Entrepreneurial Behaviour \& Research, 5(6), 279-296.

Timmons, JA. (1994). New venture creation: Entrepreneurship for the 21st Century (4th ed.). Burr Ridge, IL: Irwin.

Timmons, AJ, \& Spinelli, S. (2007). New Venture Creation: Entrepreneurship for the 21st Century (7 ${ }^{\text {th }}$ ed). NY: McGraw-Hill. Chapter 1.

Ucbasaran, D, Westhead, P, \& Wright, M. (2009). The extent and nature of opportunity identification by experienced entrepreneurs. Journal of Business Venturing, 24, 99-115.

Vaghely, IP, \& Julien, PA. (2010). Are opportunities recognized or constructed? an information perspective on entrepreneurial opportunity identification. Journal of Business Venturing, 25, 73-86.

Venkataraman, S. (2003). Foreword. In S Shane (Ed.), A General Theory of Entrepreneurship: The Individual-Opportunity Nexus: xi-xii. Northampton, MA: Edward Elgar.

Williams, D. (2006). On and off the net: scales for social capital in an online era. Journal of Computer-Mediated Communication, 11(2), 1-29.

Zanakis, SH, Renko, M, \& Bullough, A. (2012). Nascent entrepreneurs and the transition to entrepreneurship: Why do people start new businesses. Journal of Developmental Entrepreneurship, 17(1), 1-25.

doi:10.1186/2251-7316-2-7

Cite this article as: Wasdani and Mathew: Potential for opportunity recognition along the stages of entrepreneurship. Journal of Global Entrepreneurship Research 2014 2:7.

\section{Submit your manuscript to a SpringerOpen ${ }^{\circ}$ journal and benefit from:}

- Convenient online submission

- Rigorous peer review

- Immediate publication on acceptance

- Open access: articles freely available online

- High visibility within the field

- Retaining the copyright to your article

Submit your next manuscript at $\boldsymbol{\sim}$ springeropen.com 